in the case of Government foresters and Commercial (salaried) foresters, the large number of replies enabled curves to be plotted for each of the five areas for each of these two groups. These are shown in Figures 3 and 4. From these graphs it may be noted that there is considerable variation in average salaries paid to foresters in various regions of the country. Generally, the salary of government foresters appears to be highest in British Columbia and lowest in the Maritimes and the Prairie provinces. On the other hand, from Figure 4 it is apparent that of the foresters in industry replying to the questionnaire those from Ontario received the highest salaries and those from the Maritimes the lowest.

In general we believe that the excellent response received indicates a high degree of interest in the salary survey among C.I.F. members. Statistics of this nature obtained by other professional associations have proved to be of value to their membership, and it is believed the same will hold true for C.I.F. members. The results obtained and the interest shown by Institute members, in the opinion of the authors, justify the continuation of the survey on an annual basis.

\title{
NEWS OF THE SECTIONS
}

\section{NEWFOUNDLAND}

There is little in the way of section activities to report at this time. As was stated previously, the Newfoundland Section is relatively new and its formation was, without doubt, a major accomplishment. It is presently being governed by a Provisional Council to hold office until such time as a formal election of officers can be held later on in the year.

Two recent graduates, Messrs. Deichmann and Broeren, arrived in Newfoundland last May. Both have become members of the C.I.F. However, no net increase in membership occurred as we lost Gordon McLeod and Hans Mandoe. They both went to the mainland for employment.

Recent personal events concerned the visit of the stork to Harold Johnson and Bill Wilton.

The writer has left the Forestry Branch and is now employed with Bowater's Pulp and Paper Mills at Corner Brook.

Contributed by. W. A. Dickson

\section{ATLANTIC}

A council meeting was held at Truro on July 5 in order to outline a programme for the section's annual meeting.

Tentative plans are to hold this meeting in Halifax on November 21 and 22 with registration and dinner at the Lord Nelson Hotel and meetings at the Y.M.C.A. Building. The theme will be "Public Relations in Forestry", and it is hoped that Dean J. Miles Gibson of the Forestry Faculty, University of New Brunswick, will deliver the theme address. There will then follow papers by various foresters and representatives of the Nova Scotia Department of 
Education, radio, television, press and forest products industries expressing their views on the subject. The meetings should prove highly successful because of the variety of approaches to this timely theme.

\section{Personalia}

Our congratulations to Dick and Ruth Bulmer on the addition to their family, also to Don and Peggy Eldridge (a girl in each case).

Ralph Redmond, formerly with the N.S. Department of Lands and Forests, has accepted a position with the New Brunswick Forest Service.

Contributed by F. G. Cuming

\section{MARITIME}

Mr. Art Van Slyke has been appointed to the staff of the Forestry Faculty at the University of New Brunswick. Art has spent the last few years at the Canadian International Paper Company Forest Experimental Station in Causapscal, Quebec. We expect to see Art taking up his new duties early this fall.

We will be holding the Maritime Section C.I.F. Annual Meeting on October 3 rd and 4th in Fredericton this year. Our Chairman, Mr. H. D. Heaney, tells me that the plans are well underway.

The Northeastern Soils Conference was held on August $20-22$. The program included visiting areas in Fredericton and at the Green River Experimental Station near Edmundston.

A Forest Fire Research Conference of the Woodlands Section, Canadian Pulp and Paper Association, was held in Charlo, N.B., on August 12th and 13th.

Mr. A. C. Dixon has been transferred from Maniwaki to Campbellton, N.B. We understand that Art will be working at the Causapscal Forest Experimental Station.

The budworm spraying program was the largest ever undertaken in this Province. It is my understanding that over five million acres were treated this spring. The first fatality was recorded when one of the pilots was killed in an airplane crash.

The New Brunswick Forest Development has completed the writing of its report.

We met Mr. Syd Heckbert the other day in Chaleurs, Quebec. Syd is now the Woodlands Manager for the Cascapedia Manufacturing and Trading Company, a subsidiary of the Bathurst Power and Paper Company in New Brunswick.

Mr. Ralph Redmond, formerly with the Nova Scotia Department of Lands and Forests, is now working in New Brunswick for the New Brunswick Department of Lands and Mines.

Contributed by BRUCE KeLLY

\section{Central Ontaruo}

No meetings of the section have been held since April; but a field meeting was held in mid-August at Ramsey, Ontario.

Some staff changes are reported among members of the section which indicate that Foresters are still among the roving kind. 
Our current section chairman, George Morrison, is now devoting his time to the pursuit of pulp and paper products at Espanola, Ontario, after spending several years at the Department of Reform Institutions at Burwash, Ontario, where he was the Resident Forester, in charge of the Burwash Management Unit.

The liquidation of the Gillett Log Company operations in the Soo area has resulted in Vic Hamilton returning to the Pineland Timber Company to work with Jack Hope who also joined them this spring in Sudbury. Ralph Forfar, late of Gillett Log, now is connected with the Roddis Lumber and Veneer Company (of Canada) Limited.

Central Ontario has lost one member by transfer to Southern Ontario but gained two. In April, Doug Hughes left the Kirkwood Management Unit at Thessalon to become Reforestation Supervisor at Tweed, Ontario, with the Department of Lands and Forests. Sandy Russell moved from the Provincial Forest Station at Orono to the Sault Ste. Marie District as Management Forester for the Sault Ste. Marie Management Unit.

W. E. McCraw joined the staff of the Roddis Lumber and Veneer Company in the Soo as Woods Manager early this year. Bill was formerly with the Caterpillar Tractor Company at Peoria, Illinois, and maintained his connection with the C.I.F. in the Southern Ontario Section. He brings to this section a wealth of experience in mechanical equipment designed for the Forester's needs in many kinds of woods operations.

John Lloyd of the Lands and Forests staff at the Soo is now at Thessalon on the Kirkwood Management Unit and John Fingland has joined the staff of the newly formed division of Guelph Plywood Limited, at Sault Ste. Marie. Contributed by D. S. BRUCE

\section{ROCKY MOUNTAIN}

Alberta Department of Lands and Forests forest survey parties under the direction of R. D. Loomis, Senior Superintendent, with field supervision by Gordon deGrace, are now established at a number of points in the Province undertaking timber stumpage sale cruises and other special studies.

A 30-man party made up of university students under Forester Doug Lyons in the vicinity of Edson is doing the mapping and timber cruising work in that region assisting the Edson Forestry Division in completing data for pending timber sales.

The party has had placed at its disposal a track "Bombadier" for transportation of personnel and equipment across muskeg areas. This represents the first occasion such a vehicle has been made available for forest field parties. The supplementary transportation unit for muskeg crossing has saved valuable time for the crews. Its superiority over the old "bush vehicle", the hardy pack horse, has been amply demonstrated. For remote areas, however, the latter transportation system still has its uses, even in this modern era of helicopters hovering over forest zones to spot crews for work from a strategic centre.

The "Bombadiers" were pioneered by the army and then adapted or improved for exploration work by oil companies. After further modification, 
they are now part of the Province's equipment. They form an important part of Forest Fire suppression, and plans call for allotment of these vehicles in each of the forest divisions.

This overall planning of the forest protection system has been directed by Forest Protection Superintendent T. R. Hammer, and Asst. Superintendent Frank Platt.

Mr. D. Moran is a recent addition to the Forest Surveys staff. Another Forester taken on the staff is Glen Paul (Montana State University - Missoula) in co-operation with the Federal Laboratory of Forest Pathology in Calgary, who is carrying out cull studies in the vicinity of Slave Lake, Alberta.

The Forest Pathology Laboratory's counterpart in this project is Dave Etheridge of the Calgary Lab. This study is a shared project between the Department of Lands \& Forests with supervision for the Department under R. D. Loomis, and Vidor Nordin, Forest Pathology Investigations Chief for Alberta. The studies will assist in establishing realistic appraisal of disease damage for cruise computations.

Nick Sousekiewicz, Forest Surveys Forester, is making a survey of Tower coverage for the entire province.

Swanson Lumber Company is continuing its woods operations in Wood Buffalo Park on the northeastern sector of Alberta. All transportation of production is by barge and scow. Tom Matty, production manager, has become a regular airplane commuter from headquarters in Edmonton to company camps in the park.

A request was received from community farmers of the Paddle River area (Pembina Tributary) for assistance in their investigations of flood prevention methods.

The Department of Lands and Forests is carrying on regional studies into the causes of flash flooding affecting farm lands of the area. These studies inevitably have led the investigators into the upper reaches of the watersheds, minor and major, and the tying in with soil conservation practices on the farms along and adjacent to the river courses.

Farmers appreciative of the role of forestry and good soil conservation practices have asked that forests be retained at stream headwaters for their function in water run-off control.

Studies are being made also of those key areas (as yet unsettled) which should be withheld from settlement.

An interesting feature of this interest of the farmers is their increasing realization of the value of forestry and water conservation practices which stemmed from their own interests in the relationship of agriculture and forestry.

They are gaining an awareness of the mutual interdependence of farm, forest, and watershed as a unit in resource planning and management.

A meeting between soil conservationists, forestry and farm groups, held in the region, revealed a considerable interest by the farmers in the studies carried out and the conservation practices outlined by the officials.

Contributed by Ron Fytche 


\section{SASKaTCHEWAN}

\section{C.I.F. Field Trip.}

A C.I.F. field trip in August took a score of members to Candle Lake, a small resort area sixty miles north-east of Prince Albert, where they were able to inspect several plots set up to study black spruce cull, the growth of white spruce, the regeneration of white spruce and the effects of root-rotting fungi. Dr. C. G. Riley and his forest pathology laboratory staff from Saskatoon were the hosts and were responsible for the tour and its smooth-running schedule.

Stand openings in white spruce caused by the white-pocket root-rot, Polyporus tomentosus, were seen as were the associated soil types. Reduced height and diameter growth and the death of branches from ground level up indicate that trees have been infected for several years. The disease does not appear to be of importance in pulpwood rotations, but only certain soils will permit a sufficiently long period of growth to produce saw-timber. The fungus spreads from root to root, causing the trees to die in groups. Poplar, it was noted, was invariably present on diseased sites.

Two methods of root inoculation with the disease were demonstrated: the one involved inserting a diseased plug into a hole drilled in the root and sealing it with paraffin, vaseline and tinfoil; the other employed only the lashing of a piece of infected wood to a root and covering the union with plastic and tinfoil.

Thinning, through poisoning trees with a chemical (Sodium arsenite), was shown as a means of alleviating the effects of the disease.

The growth plot visited showed that the death of at least one tree was attributable to the fungus, while in the black spruce area examined, the amount of cull present had been primarily caused by a rising water table although Armillaria mellea had come in later to take advantage of the situation. The regeneration plot demonstrated the dynamic nature of vegetation and showed the influence of tree cover and aspect.

\section{Work of Pathologists Featured.}

What could be considered a preliminary to the August field trip took place in Saskatoon two months before, when four pathology research workers told of their investigations of root rots, stand openings in white spruce and the effect of day length on tree dormancy.

In a corner of the Forest Biology Laboratory, cleared temporarily for the occasion of retorts, incubators and other scientific equipment, twenty-one foresters of five nationalities gathered for the meeting. The Chairman, Mr. J. M. Atkinson, conducted brief business before handing over the chair to Dr. C. G. Riley, Officer-in-Charge of the laboratory. He then introduced the speakers.

Dr. O. Vaartaja concluded, from his study of photo periodism in Douglas fir and black spruce, that species adapt themselves to different latitudes and that planting stock from seed sources as close as possible to the area to be planted should be used. Northern strains or races of a given species, for example, appear to be adapted to longer days. In the experiments, black spruce under 
twelve hours of light showed less growth than plants under eighteen hours of light. Intensity of light needed to prevent dormancy was shown to be 500 footcandles - only a little stronger than moonlight.

Mr. Herman van Groenewoud found that stand openings in sixty-fiveyear-old white spruce appeared to be associated with extremely acid conditions except where a high water table was present.

Mr. Roy Whitney described the fungus mainly responsible for the cause of root rot in the spruce stand openings and pointed out that trembling aspen, as well as black and white spruce, might be affected. The culprit is known as Polyporus tomentosus alias circinatus.

Mr. Bruce Denyer concluded the talks by describing the instigator of another root rot of white spruce (Alberta) - namely, Flamula conacens.

At the close of the meeting, Chairman Atkinson was able to take home with him a gavel which started life as a young Manitoba maple in Dr. Riley's back garden. In accepting the gift on behalf of the C.I.F., Mr. Atkinson said that it was probably the Section's first symbolic possession.

New Foresters.

Four new foresters have arrived in Prince Albert to swell the Department of Natural Resources' professional ranks.

Hugh Nisbet, a 30-year-old Scot straight from the jungles of Malaya, started as a fire-control forester in Saskatchewan but may change his affiliation soon. Educated at Edinburgh and Oxford, he took up duties as a district forest officer in Malaya in 1950. Due, however, to the imminent changeover to independent government of the Malay States, he decided to migrate to Canada.

Duane Beach, a graduate of Lakehead Technical Institute and the University of New Brunswick, has come to the Prince Albert Administrative Region as a zone forester. Married' and with one child, he previously worked in Fredericton as a sales representative for Riley Engineering Sales Ltd. Since graduating, he has also worked for the New Brunswick International Paper Co.

Taking the place of Doug. Golding, who is now working with the Department's Forest Inventory Division, is Alex Benson, 48-year-old U.N.B. graduate, who returns to Saskatchewan after an absence of nine years. For thirteen years he served as District Forester at Meadow Lake and Hudson Bay in the province. In addition, he brings to his present position a wealth of experience with the Canadian Forestry Corps and private industry.

Hugh Goodman, a 31-year-old forester of the '49 U.N.B. graduating class, arrived with his wife and three children from New Zealand earlier this year to join the Forest Management Division of the Department of Natural Resources in Prince Albert. Hugh is in charge of long-term planning, a job in which he will be well able to use his logging experience with the Abitibi Power \& Paper Co. at Iroquois Falls, Ontario, and the Kaingaroa Logging Co., "downunder".

\section{Perhaps Another Forester:}

The writer is proud to announce the birth of a son, John Oliver, to his wife, Margaret, on August 2nd. Anxious to get started, he arrived ten days early. 


\section{Monthly Meetings}

\section{NORTHWESTERN ONTARIO}

Two field trips and a panel discussion made up the three meetings held in the first quarter under the direction of our new executive. Mark Cressman conducted the section on a tour of the Thunder Bay Nursery on June 21st.

On July 19th heated discussion took place on the subject, "The role of the Individual Forester in Public Education". This topic is to be presented to the Annual Meeting by the section in October.

Abitibi's Woodlands Laboratory at Raith was the scene of the "seedling search" on August 23rd. The popularity of this tour is indicated by the number of repeat visits made annually by many of this section. Host Leo Vidlak is a first rate lecturer.

Increasing numbers of visiting foresters have been welcomed at our regular meetings. It is hoped that this trend will continue. In general, meetings are scheduled for the second last Friday of each month.

\section{Personalia}

Maurice Helie - appointed Superintendent, Valora District, Great Lakes Paper Co., Ltd.

Carl Hagstrom - appointed Superintendent, Dog River District, Great Lakes Paper Co., Ltd.

Ed Ayer (4T9) - appointed Superintendent, Manitou Trucking Company: contractors for Great Lakes Co.

Gord Longley (5T0) - Asst. District Forester, Dept. of Lands and Forests, Sault Ste. Marie.

Jack Dickinson - Asst. District Forester, Dept. of Lands and Forests, Kapuskasing.

James Rourke -- Asst. District Forester, Dept. of Lands and Forests, Port Arthur.

Contributed by E. B. AYER

\section{SOUTHERN ONTARIO}

The slate of officers prepared by the nominating committee for the 1957-58 Council was approved unanimously. The slate elected by acclamation is as follows: Chairman, J. A. Brodie; Vice-Chairman, D. H. Burton; Council, T. W. Dwight, W. K. Fullerton, J. R. Morawski, C. J. R. Wilde.

\section{April Meeting}

Mr. W. B. Greenwood, Chief, Division of Parks, Ontario Department of Lands and Forests, spoke on the Provincial Parks and the recently formed Parks Division. He outlined the status of the parks prior to 1954 and then sketched their rapid growth in the three years following the establishment of a separate division for their administration. Mr. Greenwood discussed the problems of rapid expansion in terms of equipment and personnel, and stressed particularly the acute shortage of technical personnel who had park planning experience.

In the more detailed aspect of individual park planning, Mr. Greenwood outlined the zoning system used for parking, recreational, trailer, tenting and 
other areas and pointed out the use of natural wood and stone structures to blend with the local environment.

In the broader aspect, Mr. Greenwood stressed the problem of few parks in a sixty mile radius of Toronto.

Mr. Greenwood used slides to illustrate his very entertaining and informal talk.

\section{Committees}

At the April meeting, Dean Sisam reported briefly on the developments of the Ontario Professional Foresters Association. The Provisional Council has met and is preparing recommendations in regard to application forms, standards, by-laws and fees. These will be presented to the general meeting of the Association, which is to be held in North Bay on September 6 and 7, 1957.

Dean Sisam also reported on the progress of the Land Use Committee. Under the guidance of Dean Sisam and Mr. G. A. Hills, a brief of a general nature has been prepared in the late winter for the Senate Committee on Land Use. This Committee has asked the C.I.F. to prepare a more comprehensive brief for the fall. It was moved, seconded, and motion carried that Mr. G. A. Hills be chairman of the Committee for the preparation of the new brief.

Contributed by R. D. CaRMan

\section{LAKE OF THE WOODS}

The Fourth annual meeting of the Lake of the Woods Section of the Canadian Institute of Forestry was held in Fort Frances on June 15th with twenty-five members present representing the Kenora, Sioux Lookout, Dryden, Atikokan and Fort Frances areas.

A business meeting was held during the afternoon in the Department of Lands and Forests Office with chairman Bruno Seppala directing the meeting.

Mr. Seppala read his annual report outlining the section's activities for the year. The highlights of his report were:

(1) The pressure by the section to the M.P.s for the implementation of the Canada Forestry Act. To date this action through numerous sections seems to have caused some action in that the Federal Government has increased its grant for reforestation. Also there are indications that the Federal Government will participate in the development of access roads.

(2) The Lake of the Woods Section supported the passage of the Professional Foresters Bill one hundred percent. This action should prove to be an important step in the furtherance of forestry and good forest management practices in Canada.

Reports were also given by the Treasurer and Chairman of the standing committees.

Mr. J. D. Coats, Secretary-Manager of the Canadian Forestry Association of Ontario and the past Secretary-Treasurer of the Canadian Institute of Forestry, was called upon to outline some of the activities of both organizations.

This meeting terminated the 1956-57 term of office for the following executive: B. Seppala, Chairman; N. Golder, Vice-Chairman; L. Paterson, Secretary-Treasurer; R. Boultbee, J. Keddie and R. Binger, Councillors. The 
new executive will take over at the September meeting in Dryden and will consist of Mr. N. Golder, Chairman; Mr. G. Seed, Vice-Chairman; and Messrs W. F. Beatty, J. Harrison and R. Bunney, Councillors.

The business meeting was followed by a banquet held in the Elks Hall with Mr. S. Hancock, Assistant Manager of the Steep Rock Iron Mines, being the guest speaker. Mr. Hancock gave a very interesting talk and showed slides of the development of Steep Rock.

The banquet was followed by a social and dance.

Those attending from Fort Frances were Messrs H. Henry, G. Garner, B. Seppala, N. Golder, A. G. Dougall, W. Foster, R. McLennan, G. Henker and E. F. Johnston. From Kenora, Messrs D. Start, H. Coles, J. Chalmers, D. Honeyborne, F. Hirschmann, D. Cannon and G. Cox were in attendance. Messrs D. G. Medhurst and H. Mueller attended from Atikokan, and R. Balkwell from Sioux Lookout and Messrs G. Seed, W. F. Beatty, W. Morrison and R. Bunney from Dryden.

Contributed by R. S. M. BUNNEY

\section{CARIBOO}

The Executive for 1957-58 season is: Chairman, T. P. Decie; Vice-Chairman, C. H. Goarns; Councillors, M. Isenor and H. Anderson; Section Representative, V. Heath. The new chairman appointed D. Armit as Secretarytreasurer and P. B. Bodman as Editorial Representative. Finalization and publishing of a forest practice code for the Prince George area is already on the agenda for the year.

Contributed by P. B. BODMAN

\section{VANCOUVER ISLAND}

The first meeting of the 1957-58 Season was a field trip in September to the Nanaimo Lakes logging operations of Crown Zellerbach Canada Limited where close utilization through prelogging and relogging will be the chief interest.

At a recent meeting of the Section Council (Chairman, N. V. Mason; Vice-Chairman, C. Highsted; Members, R. Lejeune; B. Dickens), the Executive was completed with the following appointments:

Secretary, R. Corregan; Treasurer, J. Kinghorn; National Representative, H. Bancroft. Committees appointed were: Program, J. Holm; Membership, R. Lejeune; Public Relations, E. Crossin; Publications, H. Kermode; Resolutions, W. Hughes, I. Mahood, and R. Foster; Manual, A. Horth; Ecological Reserves, R. Schmidt; Silviculture, R. Malcolm, Audit, E. Druce.

Contributed by R. B. Dickens 